\title{
Pengembangan Bahan Ajar Berbasis Pendekatan Saintifik pada Mata Kuliah Metodologi Penelitian
}

\author{
Dimas Qondias ${ }^{1 *}$, I Ketut Ada Winarta², Siswanto ${ }^{3}$ \\ ${ }^{123}$ Sekolah Tinggi Keguruan Dan Ilmu Pendidikan Citra Bakti Ngada-NTT
}

\begin{abstract}
Abstrak
Penelitian ini didasari atas temuan bahwa mata kuliah metodologi belum optimal, baik dari sisi konten dan kurang mampu mengembangkan daya nalar mahasiswa. Oleh karena itu, secara spesifik tujuan dari penelitian ini adalah mengembangkan bahan ajar berbasis saintifik pada mata kuliah metodologi penelitian. Penelitian ini dikembangkan dengan model ASSURE, dengan melihat aspek konten, bahasa dan desain selanjutnya akan di ujicoba terbatas pada mahasiswa STKIP Citra Bakti. Hasil penelitian menunjukkan aspek konten, desain dan bahasa dengan kategori sangat baik, serta penilaian mahasiswa dengan kategori sangat baik. Oleh karena itu,bahan ajar yang telah dikembangkan siap di implementasikan.
\end{abstract}

Keywords:

Bahan Ajar, Saintifik, Metodologi Penelitian

\section{PENDAHULUAN}

Dalam UU No. 14 Tahun 2005 Dosen adalah pendidik profesional dan ilmuwan dengan tugas utama mentransformasikan, mengembangkan, dan menyebarluaskan ilmu pengetahuan, teknologi, dan seni melalui pendidikan, penelitian, dan pengabdian kepada masyarakat. Sebagai tenaga profesional, dosen memiliki kedudukan dan peran sangat penting sebagai agen pembelajaran. UU No 12 Tahun 2012 tentang Pendidikan Tinggi juga merumuskan kewajiban dosen menulis buku ajar atau buku teks, yang diterbitkan oleh Perguruan Tinggi dan/atau publikasi ilmiah sebagai salah satu sumber belajar dan untuk pengembangan budaya akademik serta pembudayaan kegiatan baca tulis bagi Sivitas Akademika. Hal ini menjelaskan dosen dituntut untuk mengembangkan bahan ajar guna mengembangkan dan membekali pengetahuan mahasiswa.

Bahan ajar berisikan seperangkat materi yang disusun secara sistematis sehingga guru dan peserta didik dapat menggunakannya dalam proses pembelajaran dalam suasana dan lingkungan yang nyaman untuk belajar (Pannen 2001). Florence Martin (2011) mengungkapkan dalam penelitiannya untuk para pendesain pembelajaran agar mengembangkan dan mendesain pembelajaran sesuai dengan komunitas lingkungan. bahan ajar merupakan segala bahan (baik informasi, alat, maupun teks) yang disusun secara sistematis, yang menampilkan sosok utuh dari kompetensi yang akan dikuasai peserta didik dan digunakan dalam proses pembelajaran dengan tujuan perencanaan dan penelaahan implementasi pembelajaran (Prastowo, 2011). Sedangkan ditegaskan oleh Bandono (2009), bahan ajar yang baik dan lengkap seharusnya dilengkapi ilustrasi dan tugas atau latihan serta aktivitas lain yang dapat memperkuat pemahaman siswa terhadap materi dan kompetensi yang dipelajari. Jadi ilustrasi, tugas/latihan, aktivitas lain dan evaluasi yang dimasukkan sebagai kelengkapan aktivitas belajar siswa bisa berfungsi sebagai materi penguat (reinforcement).

Bahan ajar yang akan dikembangkan dalam penelitian ini adalah metodologi penelitian. Metodologi penelitian merupakan salah satu mata kuliah wajib yang di tepuh oleh seluruh mahasiswa. Menurut Dantes 2012 metodologi merupakan ilmu yang mempelajari cara-cara melakukan penelitian. Menurut Cohen., Manion \& Marison (2007) metodologi bertujuan untuk menjawab suatu fenomena hingga dapat mencapai atau menarik suatu kesimpulan, sedangan Ary, Jacobs, Lucy (2010) menguraikan bahwa 
metodologi menguraikan metode penelitian deduktif dan induktif dan menggambarkan hubungan suatu variabel dalam skala hipotesis.

Analisis awal pada mata kuliah metodologi penelitian di STKIP Citra Bakti bahwa selama ini bahan ajar yang digunakan belum sesuai dengan konten dan kurang mampu mengembangkan daya nalar mahasiswa, dalam mata kuliah ini mahasiswa dituntut untuk aktif dalam membuat keterampilan karya ilmiah yang berupa produk proposal, mengedepankan latihan-latihan yang melibatkan mahasiswa berfikir ilmiah untuk menemukan/ merumuskan suatu kajian berupa produk dalam penulisan tugas akhir. Padahal secara konseptual mata kuliah metodologi penelitian ini nantinya akan membawa mahasiswa/ bekal mahasiswa sebagai peneliti serta pijakan dari penyelesaian tugas akhir. Untuk mengejawantahkan hal tersebut perlu adanya pengembagan suatu bahan ajar metodologi penelitian yang menciptakan pembelajaran inovatif di perguruan tinggi yang sesuai dengan kondisi mahasiswa di lingkungan tersebut.

Menelisik hal tersebut pengembangan bahan ajar yang akan dilakukan dengan berbasis pendekatan saintifik, pada umumnya pendekatan ini melibatkan kegiatan pengamatan atau observasi yang dibutuhkan untuk perumusan hipotesis atau pengumpulan data. Menurut Dyer, et al (2011), ciri pendekatan saintifik yakni: 1) observasi; 2) bertanya; 3) melakukan percobaan; 4) asosiasi (menghubungkan/menalar); 5) membangun jaringan (networking). Menurut sinuraya (2016) bahwa bahan ajar yang berorientasi penyelidikan ilmiah mampu meningkatkan pencapaian hasil belajar peserta didik.

\section{METODE PENELITIAN}

Penelitian ini merupakan penelitian pengembangan (R\&D), yang dikembangkan menggunakan model ASSURE. Penelitian ini dilakukan STKIP Citra Bakti Kabupaten Ngada-Flores-NTT. Dengan merancang bahan ajar berbasis saintifik pada mata kuliah metodologi penelitian. Subyek penelitian ini mahasiswa STKIP Citra Bakti yang menempuh mata kuliah metodologi penelitian,

Data mengenai kualitas bahan ajar dilihat dari aspek desain, bahasa dan konten dianalisis secara deskriptif, untuk mengolah data hasil review ahli desain, bahasa, konten dan uji perseorangan. Teknik analisis data ini dilakukan dengan mengelompokan informasi dari data kualitatif yang berupa masukan, tanggapan, kritik, dan saran perbaikan yang terdapat pada angket. Hasil analisis ini kemudian digunakan untuk merevisi produk yang dikembangkan. Data mengenai uji kelompok dan tanggapan bahan ajar dengan memberikan kuisioner sesuai model assure. Dengan memberikan penilaian skala likert. Data mengenai efektifitas penggunaan bahan ajar dianalisis dengan statistik deskriptif.

\section{ANALISIS DAN PEMBAHASAN}

Bahan ajar hal yang penting untuk menunjang proses pembelajaran. Bahan ajar yang digunakan pun harus sesuai dengan kebutuhan mahasiswa dan sesuai dengan capaian pembelajaran mata kuliah. Bahan ajar Metodologi penelitian ini dikembangkan untuk memberikan informasi pada mahasiswa tentang cara menumbuhkan Ide menulis, sistematika penulisan karya ilmiah serta berbagai teknik menulis karya ilmiah.

Penelitian pengembangan metodologi penelitia ini melibatkan ahli konten, ahli bahasa serta ahli desain dengan menganalisis 10 aspek penilaian. Hasil penilaian ahli dari aspek konten rata-rata 4.5 dengan kategori sangat baik, aspek desain rata-rata 4.6 dengan kategori sangat baik, aspek bahasa ratarata 4,5 dengan kategori sangat baik.

Setelah dinyatakan layak melalui ketiga ahli tersebut, akan dilanjutkan pada penilaian mahasiswa tentang bahan ajar yang telah tersusun, dengan hasil sebagai berikut.

Tabel 1. Penilaian Mahasiswa Terhadap Bahan Ajar yang dikembangkan

\begin{tabular}{lrl}
\hline \multicolumn{1}{c}{ Pernyataan } & Rerata & Kategori \\
\hline 1. Bagaimana tampilan bahan ajar ini? & 4,5 & Sangat Baik \\
2. Bagaimana Cakupan (keluasan dan kedalaman) isi /uraian materi & 4,5 & Sangat Baik \\
3. Bagaimana Keruntutan struktur organisasi/urutan isi materi & 4,6 & Sangat Baik \\
4. Bagaimana Kejelasan dan kesesuaian bahasa yang digunakan & 4,6 & Sangat Baik \\
5. Bagaimana Kejelasan Tujuan pembelajaran/kompetensi & 4,7 & Sangat Baik \\
6. Apakah isi materi dapat memotivasi dalam belajar? & 4,6 & Sangat Baik \\
7. Bagaimana Kejelasan petunjuk pengerjaan soal latihan/tes & 4,5 & Sangat Baik \\
\hline
\end{tabular}




\begin{tabular}{lll}
\hline \multicolumn{1}{c}{ Pernyataan } & Rerata & Kategori \\
\hline 8. Bagaimana Keseimbangan proporsi soal latihan/tes dengan isi materi & 4,5 & Sangat Baik \\
9. Rerata Keseluruhan & 4,5 & Sangat Baik \\
\hline
\end{tabular}

Penilaian bahan ajar yang telah dikembangkan dari ahli konten, desain dan bahasa menunjukkan bahwa bahan ajar yang telah di kemas dengan kategori sangat baik. Ini berarti tingkat kelayakan bahan ajar metodologi ini layak untuk digunakan pada kalangan mahasiswa yang dimakana lebih mengedepankan ciri lingkungan para pebelajar. Penilaian mahasiswa pun seiring dengan hasil kelayakan para ahli, penilaian mahasiswa menyatakan bahwa bahan ajar yang dikembangkan dengan penilaian atau kategori baik. Hal tersebut sesuai yang di ungkapkan Matthew. C Nwike (2013); Tanyanyiwa, \& Mutambanengwe, (2015) Bahwa peserta didik akan lebih baik belajarnya dengan menggunakan bahan ajar yang dibuat oleh pendidik. Lebih lanjut lagi Sareb (2007), Joyce (2009) menyatakan bahwa buku ajar sebagai salah satu perangkat pembelajaran merupakan kelengkapan yang mutlak diperlukan dalam proses belajar mengajar karena buku ajar dapat menjadi jembatan yang efektif dalam penyampaian materi pelajaran.

Pembelajaran diperguruan tinggi adalah pembelajaran andragogis karena pembelajar (mahasiswa) adalah orang-orang dewasa yang mempunyai pengalaman-pengalaman menarik sebagai bahan diskusi serta mereka pula yang memiliki kemampuan dan kemandirian untuk belajar. Dengan adanya buku ajar dosen tidak perlu terlalu banyak menyajikan materi didalam kelas sehingga kesempatan dosen untuk untuk membimbing mahasiswa menjadi lebih banyak, sehingga mahasiswa dapat belajar lebih efektif (Senguin 1990).

\section{KESIMPULAN}

Kebutuhan terhadap pengembangan bahan ajar metodologi penelitian berbasis saintifik telah sesuai dengan kelayakan dari segi konten, bahasa dan desain serta mampu meningkatkan penalaran mahasiswa untuk berfikir logis dan ilmiah. Pengembangan bahan ajar perlu dikembangan pada mata kuliah lainnya sesuai dengan kebutuhan karakteristik mahasiswa sehingga mampu menciptakan pembelajaran yang lebih menyenangkan.

\section{DAFTAR PUSTAKA}

Ary, Donald., Jacobs, Lucy Cheser., Sorensen Christine. 2010. Introduction to Research in Education (Eighth Edition). Wadshwort: Belmoth CA.

Cohen, Luis., Manion, Lawrence \& Marison, Keith. 2007. Research Method in Education. Routledge: New York

Dantes, Nyoman. 2012. Metodologi Penelitian. Yogyakarta: CV Andi Offset

Dyer, J, Gregersen. 2011. The Innovator's (Sani Ridwan, Abdullah. 2014). Pendekatan saintifik Untuk Implementasi Kurikulum 2013. Jakarta: Bumi Aksara

Florence Martin. 2011. Instructional Design And The Importance Of Instructional Alignment. Community College Journal of Research and Practice. 35: 955-972

Joyce Bruce,dkk. 2009. Models Of Teaching: Model-model pengajaran , Edisi ke-8, Yogyakarta: Pustaka Pelajar.

Matthew. C Nwike. 2013. Effects of Use of Instructional Materials on Students

Cognitive Achievement in Agricultural Science. Journal of Educational and Social Research. 2(5): 103-107

Pannen P dan Purwanto. 2001. Penulisan Bahan Ajar. Jakarta: Depdiknas.

Pemerintah Republik Indonesia. UU No. 14 Tahun 2005 tentang Guru dan Dosen

Pemerintah Republik Indonesia. UU No 12 Tahun 2012 tentang Pendidikan Tinggi. 
Prastowo, andi. 2011. Panduan Kreatif Membuat Bahan Ajar Inovatif. Jogjakarta: Diva Press

Sareb, Putra, R. Masri. 2007. How to Write Your Own Text Book. Bandung: Qolbu

Seguin. R. 1990. The Elaboration of School Textbooks. Methodological Guide. UNESCO

Tanyanyiwa, V. I., \& Mutambanengwe, B. 2015. Department Involvement in Instructional Materials Development for ODL Study at the Zimbabwe Open University (ZOU). Journal of Learning for Development, 2(2) 